\title{
PENGARUH PENGASUHAN KENABIAN TERHADAP KECENDERUNGAN KENAKALAN REMAJA
}

\author{
Arini Mukhlisah ${ }^{1}$, Ahmad Yasser M², Kurniati Zainuddin ${ }^{3}$ \\ 1,2,3Fakultas Psikologi Universitas Negeri Makassar \\ 1,2,3Kampus UNM: Jalan Raya Pendidikan No 1 Makassar, 90222 \\ Email: arinienterpreneur@yahoo.com ${ }^{1}$, ahmadyasser_mansyur@yahoo.com², \\ kurniazainuddin@gmail.com ${ }^{3}$
}

\begin{abstract}
Abstrak:
Kecenderungan kenakalan remaja adalah kemungkinan remaja berperilaku menyimpang dan bersifat melawan hukum, anti susila, dan menyalahi norma-norma agama. Penelitian ini bertujuan untuk mengetahui pengaruh pengasuhan kenabian terhadap kecenderungan kenakalan remaja. Sampel dalam penelitian ini adalah 97 orang remaja di SMA yang berusia 15-17 tahun. Pengumpulan data dilakukan dengan dua instrumen penelitian, yaitu skala kecenderungan kenakalan remaja dan skala pengasuhan kenabian. Analisis data dilakukan dengan metode regresi linear sederhana. Hasil penelitian menunjukkan bahwa terdapat hubungan negatif antara kecenderungan kenakalan remaja terhadap pengasuhan kenabian, $r=-0,484(p=0,000)$. Artinya semakin tinggi pengasuhan kenabian, maka semakin rendah kecenderungan kenakalan remaja. Penelitian ini diharapkan dapat memberikan informasi kepada orangtua agar dapat mengurangi resiko kenakalan remaja dengan menerapkan pengasuhan kenabian.
\end{abstract}

\begin{abstract}
:
The tendency of juvenile delinquency is a possibility of deviating behavior and is against the law, anti-morality, and violate religious norms. This study aimed to determine the effect of parenting prophetic against the tendency of juvenile delinquency. The sample in this study was 97 adolescences in high school aged 15-17 years. The data collection was done by using two research instruments, they were the scale of the tendency of juvenile delinquency and parenting scale prophetic. The data analysis was performed using simple linear regression. The results showed that there was a negative correlation between juvenile delinquency propensity towards nurturing prophetic, $\mathrm{r}=-0.484(\mathrm{p}=$ 0.000 ). This means that the higher the prophetic care, the lower the tendency of juvenile delinquency. The study was expected to provide information to parents in order to reduce the risk of juvenile delinquency by applying parenting prophetic.
\end{abstract}

\section{Kata kunci:}

Pengasuhan, kenakalan, remaja,

USIA remaja dianggap sebagai usia yang kritis dan rentan dengan masalah. Hurlock (1980) mengemukakan bahwa masa remaja merupakan periode badai dan tekanan, yaitu suatu masa ketegangan emosi yang meninggi sebagai akibat dari perubahan fisik dan kelenjar. Astuti (2004) menjelaskan bahwa remaja memiliki kondisi jiwa yang labil dan sensitif. Kondisi tersebut membuat remaja mudah melakukan perbuatan yang menyimpang dari norma masyarakat. Remaja di masa transisi banyak menghadapi masalah sehingga memerlukan bimbingan dan perhatian terutama dari orangtuanya. 
Kenakalan remaja di Kota Makassar terus meningkat sebagaimana data yang dihimpun dari Polrestabel Makassar bahwa kenakalan remaja yang terjadi di kota Makassar dari tahun 2007 sebanyak 315 kasus, 2008 sebanyak 367 kasus, 2009 sebanyak 421 kasus, 2010 sebanyak 469 kasus, 2011 sebanyak 489 kasus (Sari, 2013). Pada tahun 2015 terjadi peningkatan tindak kenakalan remaja, tawuran dan juga tidak kriminal seperti pencurian bahkan tindak pembuhuhan (Fauzi, 2015). Hal tersebut sesuai pernyataan wali kota Makassar bahwa kenakalan remaja menjadi fenomena yang semakin banyak terjadi seperti geng motor, narkoba dan seks bebas (Fajar, 2016). Kenakalan remaja yang juga sering tejadi adalah bolos sekolah. Seperti kasus terjaringnya 24 pelajar SMA dari 9 sekolah oleh Tim Bhabinkamtibmas (Upeks Fajar, 2016).

Kenakalan yang melawan aturan juga terjadi di salah satu sekolah baik sekolah umum maupun sekolah Islam. Kenakalan yang dimaksudkan adalah terdapat siswa yang melakukan pelanggaran seperti terlambat sekolah, tidak mengerjakan tugas dari sekolah, mencontek, tidak mengenakan seragam, tidak masuk sekolah tanpa keterangan, dan berkelahi.

Survei yang dilaksanakan pada bulan Mei 2015 dengan memberikan kuesioner kepada 40 siswa di SMA W 40 siswa yang merupakan subjek diberi pertanyaan mengenai perilaku kenakalan remaja. Hasil data awal menunjukkan sebanyak 22 siswa (55\%) tidak pernah berkelahi di sekolah dan 18 siswa (45\%) yang pernah berkelahi di sekolah. Selain itu pelanggaran lain yang terjadi di SMA W adalah bolos sekolah, data menunjukkan sebanyak 16 siswa (40\%) pernah bolos sekolah dan 24 siswa $(60 \%)$ yang tidak bolos sekolah. Hasil survei menunjukkan bahwa terdapat kecenderungan kenakalan remaja di SMA W.

Orangtua menjadi pihak yang paling bertanggung jawab atas keterpurukan perilaku anak. Perilaku anak menjadi tanggung jawab orangtua sebagai pendidik utama. Scohib (1998) mengemukakan situasi dan kondisi keluarga yang negatif menjadi sebab utama terjadinya kenakalan remaja, seperti: perkelahian antar remaja, seks bebas, bolos sekolah, dan minum minuman keras.

Hasil penelitian yang dilakukan oleh Astuti (2004) menunjukkan bahwa pengasuhan orangtua memberikan pengaruh terhadap munculnya gejala kenakalan remaja yaitu memberikan sumbangan 19.4\%. Pengasuhan model permisif memberikan sumbangan terbesar terhadap munculnya kenakalan remaja karena memberikan kebebasan secara berlebihan pada anak. Hasil penelitian Murtiyani (2011) menunjukkan bahwa dari semua orangtua di RW V Kelurahan Sidokare Kecamatan Sidoarjo Kabupaten Sidoarjo sebagian besar menggunakan pengasuhan otoriter, dan cenderung mempengaruhi kenakalan remaja, yaitu semakin tinggi tingkat pengasuhan orangtua (otoriter), maka tingkat kenakalan remaja juga akan semakin tinggi. Hasil penelitian Sari (2013) menunjukkan bahwa kebanyakan kenakalan remaja di Kota Makassar terjadi karena faktor pengasuhan orangtua yang permisif sehingga anak kurang mendapatkan pengawasan dari orangtua.

Penelitian tersebut menunjukkan beberapa model pengasuhan yang telah orangtua terapkan, yaitu model pengasuhan otoriter, pengasuhan permisif, dan pengasuhan demokratis. Ketiga model pengasuhan merupakan model pengasuhan yang bersifat konvensional. Beberapa hasil penelitian tersebut, menunjukkan bahwa pengasuhan konvensional terutama pengasuhan permisif 
dan otoriter yang diterapkan orangtua dapat meningkatkan kenakalan remaja. Hal tersebut sejalan dengan Fatimah, Hayati, Hamidin, Sukki, dan Anita (2014) yang mengemukakan bahwa pengasuhan permisif dan otoriter memberikan dampak negatif terhadap pembentukan perilaku anak.

Aspek religiusitas sangat penting dalam membentuk akhlak dan karakter yang baik pada anak. Nilai-nilai religiusitas yang dimiliki oleh seseorang memberikan pengaruh besar terhadap terjadinya kenakalan remaja. Hal tersebut juga sesuai hasil penelitian Palupi (2013) bahwa religiusitas berpengaruh terhadap kenakalan remaja pada siswa SMP Negeri 02 Slawi.

Palupi (2013) menjelaskan bahwa remaja yang memiliki religiusitas maka semakin rendah tingkat kenakalan pada remaja, yang dimaksud adalah remaja berperilaku sesuai dengan ajaran agama yang dianut sehingga individu berusaha menginternalisasikan ajaran agama sebagai tujuan utama hidupnya. Hal tersebut terjadi karena agama mendorong penganutnya untuk berperilaku baik dan bertanggung jawab atas perbuatannya.

Muallifah (2009) menjelaskan bahwa pengasuhan konvensional lebih fokus pada gaya atau model orangtua dalam mendidik anak. Berbeda dengan Pengasuhan kenabian yang menitikberatkan pada hal-hal yang seharusnya dilakukan orangtua berdasarkan nilai-nilai islami. Secara umum, Pengasuhan kenabian adalah mempersiapkan generasi muda yang memiliki moral yang mengacu pada nilai religiusitas.

Pengasuhan kenabian adalah pengasuhan anak menurut sunnah Nabi Muhammad dan didasarkan pada nilai keilahian yang berdasarkan al-Qur'an (Suwaid, 2014). Orangtua yang menerapkan Pengasuhan kenabian menanamkan nilai-nilai islami di dalam keluarga. Hal ini sesuai hasil wawancara dengan guru bimbingan konseling di SMA $W$ bahwa sebagian orangtua siswa di SMA tersebut mempelajari nilai-nilai religiusitas dari al-Qur'an dan Sunnah Nabi Muhammad saw. Orangtua di SMA W juga mengikuti kajian islam yang berisi materi tentang pengasuhan islami, sehingga diharapkan orangtua menerapkan pengasuhan kenabian. Namun, dalam mendidik anak, orang tua di SMA W belum menerapkan pengasuhan kenabian dengan baik. Salah seorang siswa di SMA W menjelaskan bahwa terkadang orangtua sulit menahan emosi jika anak melakukan kesalahan, seperti orangtua langsung mencela dan bahkan memukul anak dengan keras. Orangtua tidak menerapkan tuntunan Nabi Muhammad saw agar sabar dalam menghadapi anak yang melakukan kesalahan, sehingga diduga hal tersebut menjadi salah satu sebab terjadinya tindak kenakalan remaja di SMA W.

Penerapan pengasuhan kenabian di dalam keluarga akan memengaruhi karakter dan perilaku seorang anak. Hal ini sesuai dengan pendapat Ahmad (2008) bahwa Pengasuhan kenabian adalah pengasuhan dari nabi yang memperhatikan dan membentuk perilaku anak, pendidikan akhlak dan perilaku. Fatimah, dkk. (2014) juga mendukung bahwa pengasuhan kenabian merupakan model pengasuhan terbaik dan paling banyak berpengaruh positif kepada anak jika dibandingkan dengan pengasuhan konvensional. Berdasarkan permasalahan yang diuraikan, peneliti akan menguji pengaruh pengasuhan kenabian terhadap kecenderungan kenakalan remaja. 


\section{KENAKALAN REMAJA}

Remaja (adolescence) adalah tumbuh menjadi dewasa (Hurlock, 1980). Lebih lanjut Hurlock (1980) mengemukakan bahwa masa awal remaja berada pada usian 13-16 tahun dan akhir remaja awal berawal dari usia 16-17 tahun sampai 18 tahun. Awal masa remaja dikenal dengan istilah "usia belasan" atau disebut sebagai "usia belasan yang tidak menyenangkan". Istilah ini muncul karena dikaitkan dengan perilaku khas remaja yang memperlihatkan bahwa remaja belum matang pada usia tersebut.

Remaja secara tradisional merupakan periode "badai dan tekanan". Pada masa ini memiliki masa ketegangan emosi meninggi sebagai akibat dari perubahan fisik dan kelenjar. Emosi yang meninggi disebbakan karena remaja berada dibawah tekanan sosial dan menghadapi kondisi baru (Hurlock, 1980). Namun demikian tidak semua remaja mengalami masa badai dan tekanan akibatnya banyak remaja mengalami ketidakstabilan dari waktu ke waktu sebagai konsekuensi dari usaha penyesuaian pola perilaki baru dan harapan sosial baru. Hal ini yang dapat menjadi pemicu remaja cenderung melakukan perilaku menyimpang yang sering disebut dengan istilah kenakalan remaja.

Rahmawati (Mansyur, 2001) mengemukakan bahwa kecenderungan kenakalan remaja adalah tinggi rendahnya kemungkinan remaja berperilaku menyimpang dan bersifat dan melawan hukum, anti susila, dan menyalahi norma-norma agama. Kecenderungan ini akan muncul dalam bentuk perilaku menyimpang jika remaja berada dalam situasi yang memaksa untuk berprilaku menyimpang. Santrock (1995) mendefinisikan kecenderungan kenakalan remaja sebagai suatu rentang perilaku yang luas, mulai dari perilaku yang tidak dapat diterima secara sosial seperti melakukan kesalahan disekolah, melakukan pelanggaran dirumah, dan melakukan tindakan kriminal seperti mencuri. Sarwono (2011) mendefinisikan kenakalan remaja sebagai perilaku menyimpang dari kebiasaan atau melanggar hukum. M. Gold dan J. Petronio (Sarwono, 2011) mendefinisikan bahwa kenakalan remaja adalah tindakan seseorang yang belum dewasa yang sengaja melanggar hukum dan diketahui bahwa tindakan yang dilakukan jika diketahui oleh petugas hukum maka akan dikenai hukuman.

Jensen (Sarwono, 2011) membagi kenakalan menjadi empat jenis, yaitu :

a. Kenakalan yang menimbulkan korban fisik pada orang lain, misalnya: perkelahian, menyakiti teman seperti melakukan penganiayaan dan lain-lain.

b. Kenakalan yang menimbulkan korban materi, misalnya: perusakan, pencurian, pemerasan, menggunakan iuran sekolah (SPP) dan lain-lain.

c. Kenakalan sosial yang tidak menimbulkan korban di pihak orang lain, misalnya: menikmati karya pornografi, penyalahgunaan obat dan hubungan seks bebas.

d. Kenakalan yang melawan status, misalnya: mengingkari status anak sebagai pelajar.

\section{PENGASUHAN}

Scohib (1998) mengemukakan bahwa pengasuhan menjadi sebab terjadinya kenakalan remaja. Penelitian Arifin dan Hambali (Schohib, 1998) membuktikan bahwa kenakalan remaja di Jawa Timur disebabkan pengasuhan orangtua terhadap anaknya seperti tingkat otoritas orangtua dan miskinnya 
teladan keagamaan dari orangtua. Sehingga Pengasuhan orangtua juga menjadi faktor penyebab utama terjadinya kenakalan remaja. Palupi (2013) menjelaskan bahwa faktor rational choice yang dikemukakan oleh Jensen menjadi salah satu sebab terjadinya kenakalan remja. Pada faktor ini remaja lebih mementingkan faktor individu. Kenakalan yang dilakukan adalah atas pilihan, interest, motivasi atau kemaunnya sendiri. Misalnya kenakalan remaja disebabkan karena kurangnya nilai religiusitas dan keimanan dalam diri remaja tersebut.

Pengasuhan kenabian adalah pengasuhan anak menurut sunnah Nabi Muhammad, pengasuhan yang didasarkan pada nilai keilahian. Konsep yang mengajarkan kewajiban dan sunnah dalam agama (Suwaid, 2014). Ulwan (2014) menjelaskan Pengasuhan kenabian adalah cara nabi mendidik anak, yang tetap berdasarkan Qur'an dan sunnah, yang nilainya berasal dari pendidikan anak dalam islam. Ashari (2014) menyatakan pengasuhan kenabian adalah konsep pengasuhan dalam keluarga dengan basis kenabian, mulai dari landasan, aplikasi, hingga hasil, dan evaluasi.

Ahmad (2008) menjelaskan bahwa pendidikan anak dalam islam adalah pengasuhan dari nabi yang memerhatikan teori tentang tabiat anak, pertumbuhan sosial, dan pendidikan akhlak dan perilaku. Lebih lanjut Ahmad (2008) menjelaskan bahwa pendidikan yang diajarkan oleh Nabi mengandung semua prinsip yang terdapat pada pendidikan modern yaitu self education, ilmu untuk keahlian praktis, perbedaan individual, pengembangan bakat dan kreativitas. Pendidikan Islam adalah pengajaran dari Al-Qur'an dan hadits Rasulullah shallallahu alaihi wa sallam yang tidak mengandung kebatilan, kekurangan, maupun kesalahan. Aspek pengasuhan kenabian terdiri atas Ibadah, Akhlak, Komunikasi, Hak anak, Hiburan, dan Hukuman (Suwaid dan Ulwan, 2014).

Hasil penelitian yang dilakukan oleh Astuti (2004) menunjukkan bahwa pengasuhan orangtua memberikan pengaruh terhadap munculnya gejala kenakalan remaja yaitu memberikan sumbangan $19.4 \%$. Pengasuhan model permisif memberikan sumbangan terbesar terhadap munculnya kenakalan remaja karena memberikan kebebasan secara berlebihan pada anak. Hasil penelitian Murtiyani (2011) menunjukkan bahwa dari semua orangtua di RW V Kelurahan Sidokare Kecamatan Sidoarjo Kabupaten Sidoarjo sebagian besar menggunakan pengasuhan otoriter, dan cenderung mempengaruhi kenakalan remaja, yaitu semakin tinggi tingkat pengasuhan orangtua (otoriter), maka tingkat kenakalan remaja juga akan semakin tinggi.

Ihsan dan Atsari (2014) menjelaskan orangtua adalah pendidik dan sosok teladan pertama bagi anak. Seorang anak tumbuh sesuai pendidikan yang diajarkan oleh orangtua. Prilaku anak yang positif berdasarkan teladan dan pendidikan yang orangtua berikan. Begitu juga, tindakan anak yang keras dan buruk karena pendidikan yang diberikan dan karakter orangtua. Abu Al-Ala' (Ahmad, 2008) mengungkapkan bahwa seorang anak tumbuh dan berkembang menjadi remaja sesuai dengan yang diajarkan oleh orangtuanya. Ahmad (2008) mengemukakan bahwa salah satu faktor dominan yang memengaruhi pembentukan karakter dan perilaku seorang anak adalah kondisi lingkungan keluarga. 


\section{METODE PENELITIAN}

Penelitian ini menggunakan pendekatan kuantitatif dengan jenis penelitian korelasional untuk melihat hubungan dan pengaruh antar variabel. Variabel bebas dalam penelitian ini adalah pengasuhan kenabian. Ulwan (2014) menjelaskan Pengasuhan kenabian adalah cara nabi mendidik anak, yang tetap berdasarkan Qur'an dan sunnah, yang nilainya berasal dari pendidikan anak dalam islam. Variabel terikat dalam penelitian ini adalah kecenderungan kenakalan remaja.

Rahmawati (Mansyur, 2001) mengemukakan bahwa kecenderungan kenakalan remaja adalah tinggi rendahnya kemungkinan remaja berprilaku menyimpang dan bersifat dan melawan hukum, anti susila, dan menyalahi norma-norma agama. Kecenderungan ini akan muncul dalam bentuk perilaku menyimpang jika remaja berada dalam situasi yang memaksa untuk berprilaku menyimpang. Populasi dalam penelitian ini adalah 135 siswa SMA W. Jumlah sampel pada penelitian ini adalah 97 orang, yang diperkirakan dari tabel Krejcie dan Morgan untuk jumlah populasi 135 orang (Krejcie \& Morgan, 1970).

Teknik pengumpulan data yang digunakan dalam penelitian ini menggunakan kuesioner untuk pengambilan data awal penelitian dan alat ukur dalam bentuk skala pengasuhan kenabian dan skala kecenderungan kenakalan remaja. Alat ukur disusun oleh peneliti. Penskalaan dalam penelitian ini mengikuti model skala Likert menggunakan alternatif jawaban dan terdiri dari dua aitem, aitem favourable dan unfavourable (Azwar, 2010). Teknik analisis data untuk menguji hipotesis dalam penelitian ini adalah menggunakan Analisis Regresi Linier Sederhana

\section{HASIL DAN PEMBAHASAN}

\section{Deskripsi kecenderungan kenakalan remaja}

Subjek penelitian adalah siswa SMA W kelas X dan XI. Subjek memiliki orang tua beragama Islam. Subjek yang berpartisipasi dalam penelitian ini berjumlah 97 orang. Gambaran deskriptif subjek penelitian seperti digambarkan pada tabel berikut:

Tabel 1. Distribusi Subjek Penelitian

\begin{tabular}{cllcc}
\hline Demografi & & Frekuensi & Persentase (\%) \\
\hline Jenis Kelamin & 1. & Laki-Laki & 37 & 38 \\
& 2. & Perempuan & 60 & 62 \\
\hline Kelas & 1. & X (sepuluh) & 81 & 83 \\
& 2. & XI (sebelas) & 16 & 17 \\
\hline
\end{tabular}

Penelitian menggunakan dua jenis kategorisasi yaitu kategorisasi mean hipotetik dan mean empirik. Data hipotetik merupakan data yang diharapkan ada pada skala dan diisi oleh subjek, sedangkan data empirik adalah data lapangan yang diperoleh dari respon subjek pada skala penelitian. Deskripsi hasil penelitian terkait kecenderungan kenakalan remaja disajikan pada tabel berikut: 
Tabel 2. Deskripsi Kecenderungan Kenakalan Remaja

\begin{tabular}{|c|c|c|c|c|c|c|c|c|c|}
\hline \multirow{3}{*}{ Variabel } & \multirow{3}{*}{$\mathbf{N}$} & \multirow{2}{*}{\multicolumn{2}{|c|}{$\begin{array}{c}\text { Hipotetik } \\
\text { Skor }\end{array}$}} & \multirow{3}{*}{ Mean } & \multirow{3}{*}{ SD } & \multirow{2}{*}{\multicolumn{2}{|c|}{$\begin{array}{c}\text { Empirik } \\
\text { Skor }\end{array}$}} & \multirow{3}{*}{ Mean } & \multirow{3}{*}{ SD } \\
\hline & & & & & & & & & \\
\hline & & Min & $\operatorname{Max}$ & & & Min & Max & & \\
\hline $\begin{array}{l}\text { Kecenderungan } \\
\text { Kenakalan } \\
\text { Remaja }\end{array}$ & 97 & 0 & 100 & 50 & 16,6 & 1 & 58 & 22,8 & 13,4 \\
\hline
\end{tabular}

Selanjutnya hasil kategorisasi dan interpretassi skor kecenderungan kenakalan remaja yang merupakan hasil penelitian ini disajikan sebagai berikut:

Tabel 3. Kategorisasi skor kecenderungan Kenakalan Remaja

\begin{tabular}{ccc}
\hline Kategori & Frekuensi & Persentase \\
\hline Tinggi & 0 & 0 \\
Sedang & 21 & 21,6 \\
Rendah & 76 & 78,4 \\
\hline Total & 97 & 100 \\
\hline
\end{tabular}

Berdasarkan deskripsi data kecenderungan kenakalan remaja dapat diketahui bahwa tidak ada siswa yang memiliki kecenderungan kenalakan remaja yang tinggi, 21 siswa $(21,6 \%)$ yang memiliki kecenderungan kenakalan remaja yang sedang, dan sebanyak 78 siswa $(78,4 \%)$ yang berada pada kategori rendah.

\section{Deskripsi pengasuhan kenabian}

Skala pengasuhan kenabian terdiri atass 25 item dengan skor penskalaan 0 sampai dengan 4 . Hasi perhitungan data hasil penelitian tentang pengasuhan kenabian disajkan pada tabel berikut:

Tabel 4. Deskripsi data pengasuhan kenabian

\begin{tabular}{|c|c|c|c|c|c|c|c|c|c|}
\hline \multirow{3}{*}{ Variabel } & \multirow{3}{*}{$\mathbf{N}$} & \multirow{2}{*}{\multicolumn{2}{|c|}{$\begin{array}{c}\text { Hipotetik } \\
\text { Skor }\end{array}$}} & \multirow{3}{*}{ Mean } & \multirow{3}{*}{ SD } & En & & \multirow{3}{*}{ Mean } & \multirow{3}{*}{ SD } \\
\hline & & & & & & \multicolumn{2}{|c|}{ Skor } & & \\
\hline & & Min & Max & & & Min & Max & & \\
\hline $\begin{array}{l}\text { Pengasuhan } \\
\text { Kenabian }\end{array}$ & 97 & 0 & 100 & 50 & 16,6 & 48 & 96 & 80,7 & 19,8 \\
\hline
\end{tabular}

Berdasarkan tabel 4 di atas tampak bahwa berdasarkan data empirik diperoleh skor minimal 48 dan skor maksimal 96 dengan mean 80,7 dan standar deviasi 9,8. Selanjutnya kategorisasi skor pengasuhan kenabian disajikan pada tabel berikut:

Tabel 5. Kategorisasi skor pengasuhan kenabian

\begin{tabular}{ccc}
\hline Kategori & Frekuensi & Persentase \\
\hline Tinggi & 65 & 67 \\
Sedang & 32 & 33 \\
Rendah & 0 & 0 \\
\hline Total & 97 & 100 \\
\hline
\end{tabular}


Berdasarkan data pengasuhan kenabian dapat diketahui bahwa terdapat 65 siswa $(67 \%)$ yang mendapatkan pengasuhan kenabian yang tinggi dan 32 siswa (33\%) yang mendapatkan pengasuhan kenabian yang sedang, dan tidak ada siswa yang berada pada pengasuhan kenabian kategori rendah.

Hasil uji normalitas menunjukkan nilai variabel pengasuhan kenabian $0,128(\mathrm{p}>0,05)$ dan variabel $0,98(\mathrm{p}>0,05)$. Dapat disimpulkan bahwa residual data berdistribusi normal dan memenuhi asumsi normalitas untuk analisis regresi linier sederhana.

\section{Pengaruh Pengasuhan Kenabian terhadap kecenderungan kenakalan remaja}

Pegujian hipotesis untuk mengetahui pengaruh pengasuhan kenabian terhadap kecenderungan kenakalan remaja dianalisis dengan menggunakan regresi linear sederhana dengan terlebih dahulu menguji asumsi normalitas dengan menggunakan uji Kolmogorv-Smirnov dan uji linieritas.

Hasil yang diperoleh dari uji normalitas adalah bahwa residual data berdistribusi normal dengan nilai sig. 0,128 $>0,05$ untuk variabel pengasuhan kenabian dan nilai sig. 0,98 >0,05 untuk variabel kecenderungan kenakalan remaja. Sementara hasil uji liniearitas pada kedua variabel adalah signifikansi linearity dengan nilai sig. 0,000 < 0,05, sehingga disimpulkan bahwa data bersifat linier. Oleh karena itu model regresi linier sederhana dapat digunakan untuk anaisis selanjutnya dalam hal memprediksi pengaruh variabel pengasuhan kenabian terhadap kecenderungan kenakalan remaja.

Uji hipotesis dengan analisis regresi linier sederhana menggunakan bantuan SPSS 16.0 for windows disajikan pada tabel beikut:

Tabel 6. Hasil uji hipotesis

\begin{tabular}{cccc}
\hline Variabel & R & R-Square & Ket \\
\hline $\begin{array}{c}\text { Kecenderungan } \\
\text { Kenakalan } \\
\text { Remaja }\end{array}$ & $-0,484$ & 0,235 & Signifikan \\
& & & \\
\hline
\end{tabular}

Berdasarkan tabel 6 di atas, tampak bahwa nilai koefisien korelasi antara variabel pengasuhan kenabian dengan kecenderungan kenakalan remaja sebesar -0,484 atau berkorelasi negatif. Selanjutnya mengetahui koefisien regresi dapat dilihat pada tabel berikut:

Tabel 7. Hasil analisis regresi linear sederhana

\begin{tabular}{|c|c|c|c|}
\hline Model & $\begin{array}{c}\begin{array}{c}\text { Unstandardized } \\
\text { Coefficient }\end{array} \\
\text { B }\end{array}$ & $\mathrm{T}$ & Sig. \\
\hline Constant & 76,31 & 7,647 & 0,000 \\
\hline $\begin{array}{l}\text { Pengasuhan } \\
\text { Kenabian }\end{array}$ & $-0,662$ & $-5,397$ & 0,000 \\
\hline
\end{tabular}


Hasil analisis regresi pada tabel 7 di atas menunjukkan bahwa nilai signifikansi $0,00<0,05$ sehingga dapat dikatakan bahwa terdapat pengaruh negatif dari pengasuhan kenabian terhadap kecendearungan kenakalan remaja.

Data kategorisasi menunjukkan bahwa tidak ada subjek yang berada pada kecenderungan kenalakan remaja kategori tinggi, 21 subjek $(21,6 \%)$ yang berada pada kategori kenakalan remaja yang sedang, dan sebanyak 76 subjek $(78,4 \%)$ yang berada pada kategori rendah. Berdasarkan hasil tersebut dapat disimpulkan bahwa sebagian besar subjek penelitian berada pada kategori rendah. Hasil tersebut sesuai yang dikemukakan oleh guru konseling SMA W bahwa masih ada siswa SMA W yang melanggar aturan-aturan sekolah meskipun kebanyakan hanya pelanggaran biasa (ringan).

Kenakalan remaja berada pada kategori rendah karena siswa memiliki religiusitas yang baik. Religiusitas siswa ditunjukkan dengan kegiatan-kegiatan islami yang dilakukan di sekolah seperti sholat berjama'ah, ceramah islam, kajian islam pekanan, kegiatan menghafal Qur'an sehingga banyak siswa yang telah menyelesaikan hafalan Qur'an. Hal ini sesuai hasil penelitian Palupi (2013) bahwa remaja yang memiliki religiusitas maka semakin rendah tingkat kenakalan pada remaja.

Data kategorisasi menunjukkan bahwa tidak ada subjek yang berada pada pengasuhan kenabian kategori rendah, 67\% responden berada pada kategori kenakalan remaja yang tinggi, dan 33\% responden yang berada pada kategori kenakalan remaja tinggi. Respon subjek dari skala pengasuhan kenabian menunjukkan bahwa subjek didik dengan nilai-nilai spiritual, seperti yang ditunjukkan pada aitem yang memiliki skor tertinggi yaitu sholat. Temuan deskriptif yang diperoleh menunjukkan bahwa orangtua memberikan pengasuhan kenabian berlandasarkan pada al-Qur'an dan sunnah. Respon subjek pada skala pengasuhan kenabian menunjukkan bahwa orangtua memberikan teladan yang baik dengan berperilaku baik, mengajarkan anak puasa dan sholat.

Ulwan (2014) menjelaskan pengasuhan kenabian adalah cara nabi mendidik anak, yang tetap berdasarkan al-Qur'an dan sunnah, yang nilainya berasal dari pendidikan anak dalam islam. Pengasuhan kenabian adalah pengasuhan anak menurut Sunnah Nabi Muhammad, pengasuhan yang didasarkan pada nilai keilahian.

Namun respon subjek pada aitem mencela menunjukkan bahwa orangtua masih sulit mengontrol emosi sehingga sering mencela anak. Bentuk tidak menahan emosi. Adhim (Rudati,2008) menjelaskan bahwa untuk dapat menjalankan pengasuhan kenabian, pengendalian emosi orangtua adalah hal yang mutlak dilakukan, disamping orangtua juga harus berpedoman pada alQur'an dan sunnah Nabi Muhammad saw.

Hasil analisis data menunjukkan bahwa terdapat pengaruh yang negatif dari pengasuhan kenabian terhadap kecenderungan kenakalan remaja. Remaja yang mendapatkan model pengasuhan kenabian yang tinggi akan memiliki kecenderungan kenakalan remaja yang rendah. Sebaliknya, remaja dengan pengasuhan kenabian yang rendah akan memiliki kecenderungan kenakalan remaja yang tinggi. 
Hasil penelitian menunjukkan semakin tinggi pengasuhan kenabian, maka semakain rendah kecenderungan kenakalan remaja. Hasil penelitian tersebut ditunjukkan dari respon subjek pada aitem mengajarkan anak sholat yang memiliki skor tertinggi pada skala pengasuhan kenabian. Tingginya skor pada aitem mengajarkan anak sholat, berpengaruh terhadap rendahnya skor item-item pelanggaran berat pada skala kecendererungan kenakalan remaja. Hasil tersebut mendukung bahwa sholat mencegah dari perbuatan keji dan munkar. Sesuai dengan firman Allah Swt di surah Al-Ankabut ayat 45: "Sesungguhnya sholat mencegah dari (perbuatan-perbuatan) keji dan mungkar."

Idealnya ketika remaja melaksanakan sholat dengan baik maka akan berusaha menghindari perilaku kenakalan. Sesuai yang dikemukakan oleh Palupi (2013) bahwa remaja yang memiliki religiusitas maka semakin rendah tingkat kenakalan pada remaja, yang dimaksud adalah remaja berperilaku sesuai dengan ajaran agama yang dianut sehingga individu berusaha menginternalisasikan ajaran agama sebagai tujuan utama hidupnya. Hal tersebut terjadi karena agama mendorong penganutnya untuk berperilaku baik dan bertanggung jawab atas perbuatannya.

Pengaruh negatif lainnya, yaitu semakin rendah pengasuhan kenabian, maka semakin tinggi kecendrungan kenakalan remaja. Hasil tersebut juga terlihat dari rendahnya respon subjek pada aitem tidak mencela anak. Hal tersebut berpengaruh pada tingginya skor aitem terlambat ke sekolah pada skala kecenderungan kenakalan remaja. Hal tersebut juga berarti bahwa masih banyak orangtua yang mencela anak sehingga berpengaruh terhadap kedisiplinanan anak di sekolah.

Hasil penelitian terebut sesuai dengan teori yang dikemukakan oleh Kurniasari (2015) bahwa pengasuhan orangtua yang mengandung kekerasan verbal berpengaruh terhadap kedisiplinan anak. Mencela anak merupakan bentuk dari kekerasan verbal. Sesuai yang dikemukakan Jessor (Nindya, 2012) bahwa orangtua yang melakukan kekerasan verbal seperti berteriak, mencela, dan mengancam akan diamati anak dan dicontoh saat berinteraksi. Patterson (Nindya, 2012) menjelaskan bahwa tindakan orangtua seperti membentak, mencaci, serta kurangnya pemberian pujian pada anak dapat meningkatkan resiko anak terlibat permasalahan perilaku yang meliputi kenakalan remaja. Siswa yang terlambat ke sekolah merupakan salah satu bentuk dari rendahnya kedisiplinan siswa. Hal ini sesuai dugaan awal peneliti bahwa salah satu satu sebab masih terjadinya tindak kenakalan remaja di SMA W karena orangtua sulit menahan emosi, seperti orangtua melakukan kekerasan verbal dengan mencela anak.

Hasil penelitian menunjukkan nilai pengasuhan kenabian subjek yang berada pada kategori yang tinggi dan sedang, serta tidak ada subjek yang berada pada kategori rendah. Hal tersebut berbanding terbalik dengan nilai kecenderungan kenakalan remaja di mana kategori rendah hanya terdiri dari 76 subjek sedangkan, 21 subjek berada pada kategori sedang, dan tidak ada subjek pada kategori tinggi. Hasil penelitian ini mendukung penelitian yang dilakukan oleh Murtiyani (2012) yang menunjukkan bahwa jenis pola asuh diterapkan orangtua dapat memengaruhi kenakalan remaja. 
Hasil penelitian ini juga didukung penelitian sebelumnya yang dilakukan oleh Adam dan Gullota (Iskandar, 2008) mengemukakan bahwa remaja yang mengalami disfungsi keluarga cenderung menunjukkan ciri-ciri berperilaku nakal dan kecenderungan terhadap obat terlarang. Jadi salah satu faktor yang memengaruhi timbulnya kenakalan remaja adalah disfungsi keluarga dimana tidak berfungsinya orangtua sebagai figur yang baik untuk anak. Salah satu metode pendidikan pengasuhan kenabian adalah hendakya orangtua menjadi suri teladan yang baik bagi anak. Sesuai yang dikemukan oleh Suwaid (2014) orangtua yang menjadi teladan baik memiliki dampak besar pada kepribadian anak. Sebab, mayoritas yang ditiru anak berasal dari orangtua. Bahkan, dipastikan pengaruh paling dominan berasal dari orangtua. Nabi Muhammad saw memerintahkan orangtua untuk menjadi teladan yang baik dalam bersikap dan berperilaku jujur kepada anak. Anak akan memerhatikan dan meneladani sikap dan perilaku orang dewasa.

Islam adalah agama yang sempurna, termasuk memberikan petunjuk untuk masalah pendidikan anak. Memerintahkan kedua orangtua untuk mendidik anak. Allah Swt berfirman di surah at-Tahrim ayat 6:

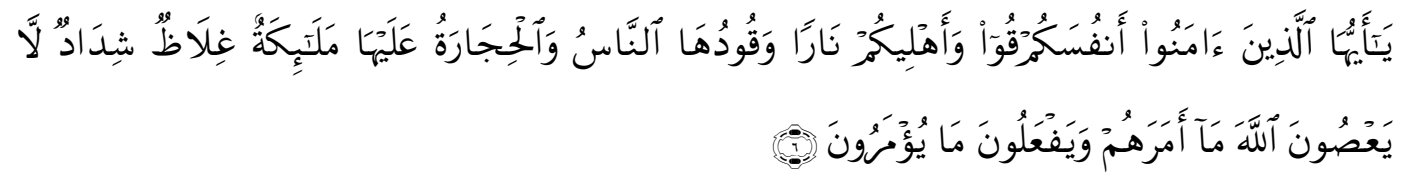

"Hai orang-orang yang beriman, peliharalah dirimu dan keluargamu dari api neraka yang bahan bakarnya adalah manusia dan batu; penjaganya malaikat-malaikat yang kasar, keras, dan tidak mendurhakai Allah terhadap apa yang diperintahkan-Nya kepada mereka dan selalu mengerjakan apa yang diperintahkan".

Allah Swt memerintahkan orangtua agar menjaga keluarga termasuk anak untuk terhindar dari api neraka. Orangtua yang menerapkan pengasuhan kenabian akan berusaha mendidik anak agar menghindari perilaku kenakalan remaja. Orangtua akan berusaha agar anak-anaknya tidak melakukan larangan Allah Swt, bentuk kenakalan remaja merupakan larangan dalam Agama Islam. Hal ini didukung oleh hasil penelitian Spencer (2013) yang menunjukkan bahwa terdapat hubungan negatif antara religiusitas keluarga dan kenakalan remaja, termasuk didalamnya interaksi suami istri dan pengasuhan orangtua.

Adhim (Rudati, 2008) mengemukakan bahwa Pengasuhan kenabian merupakan pendidikan dengan pembiasaan-pembiasaan kenabian yang baik sesuai al-Qur'an dan sunnah. Jika anak dibiasakan melakukan perbuatan yang baik,maka anak akan tumbuh menjadi remaja yang berperilaku baik. Dengan demikian, pengasuhan kenabian adalah pengasuhan yang baik, yang memengaruhi kemampuan intelektual, fisik yang bagus, termasuk perkembangan emosi dan sosial. Hal ini jelas mendukung hasil penelitian bahwa pengasuhan kenabian berpengaruh negatif terhadap kenakalan remaja.

\section{SIMPULAN}

Temuan penelitian ini adalah terdapat pengaruh negatif dari pengasuhan kenabian terhadap kecenderungan kenakalan remaja. Semakin tinggi pengasuhan kenabian, maka semakin rendah kecenderungan kenakalan remaja. 
Sebaliknya, semakin rendah pengasuhan kenabian, maka semakin tinggi kecenderungan kenakalan remaja. Penelitian menunjukkan bahwa pengasuhan kenabian berpengaruh negatif terhadap kecenderungan kenakalan remaja. Oleh karena itu, hasil penelitian diharapkan sebagai bahan pertimbangan dan masukan bagi orangtua agar mempertimbangkan aspek agama dalam pendidikan anak, khususnya untuk menerapkan pengasuhan kenabian agar menjadi solusi preventif dan kuratif Kenakalan Remaja. Selanjutnya peneliti merekomendasikan agar selanjutnya dapat meneliti faktor lain yang dapat berpengaruh pada kecenderungan kenakalan remaja misalnya teman, kecerdasan spiritual, dan kedisiplinan. Peneliti selanjutnya juga dapat meneliti pengaruh pengasuhan kenabian terhadap variabel lain, seperti religiusitas anak, intelegensi anak, dan pembentukan akhlak. Selain itu, penelitian selanjutnya bisa diujikan pada berbagai rentang usia, tidak hanya pada usia remaja.

\section{DAFTAR PUSTAKA}

Ahmad. (2008). Ensiklopedi Pendidikan Anak Dalam Islam. Jakarta: Fikr Rabbani Group.

Ashari, B. (2014). Insipirasi Dari Rumah Cahaya. Jakarta: CS Publishing.

Astuti. (2004). Pengaruh Pola Asuh Orangtua Terhadap Gejala Kenakalan Anak/Remaja Dan Penanggulanggannya. Skripsi. Tidak diterbitkan. Semarang.

Azwar, S. (2010). Sikap Manusia: Teori dan Pengukurannya. Yogyakarta: Pustaka Pelajar.

Fajar. (2016, Mei 03). Danny Pomanto Minta PKK Tekan Kenakalan Remaja. Diambil dari (http://sulsel.pojoksatu.id/read/danny-pomanto-minta-pkk-tekankenakalan-remaja/).

Fatimah, S., Hayati., Hamidin., Sukki, M., \& Anita. (2014). Parenting Interventions For Empowering Emotionally- Intelligent Parents: A Proposed Study To Parents Of Preschool Children In Selangor. International Journal of Public Health and Clinical Sciences. 1(14).

Hurlock, E.B. (1980). Psikologi Perkembangan: Suatu Pendekatan Sepanjang Rentang Kehidupan (Ed. ke-5). (Istiwidayanti \& Soedjarwo, Terj.). Jakarta: Erlangga.

Ihsan \& Al-atsari. (2014). Mencetak Generasi Rabbani. Jakarta:Pustaa Imam AsSyafi'i

Iskandar, F. (2008). Peran Keharmonisan Keluarga Terhadap Kecenderungan Kenakalan Remaja. Skripsi. Tidak diterbitkan. Makassar. Fakultas Psikologi Universitas Negeri Makassar.

Krejcie, R. V., \& Morgan, D. W.(1970). Determining Sample Educational And Psychological Measurment. 30. 607-610.

Kurniasari, A. (2015). Kekerasan Versus Disiplin Dalam Pengasuhan Anak. Socio Informa. Vol 1. No 2. 141-159.

Mansyur, A. (2001).Hubungan Antara Keagamaan Dengan Kecenderungan Kenakalan Remaja. Skripsi. Yogyakarta. Fakultas Psikologi Universitas Ahmad Dahlan.

Muallifah. (2009). Psycho Islamic Smart Parenting. Jakarta: Diva Press. 
Murtiyani. (2011). Hubungan Pola Asuh Orang Tua Dengan Kenakalan Remaja Di RW V Kelurahan Sidokare Kecamatan Sidoarjo. Jurnal Keperawatan. 01.3052.

Nindya. (2012). Hubungan Antara Kekerasan Emosional Pada Anak Terhadap Kecenderungan Kenakalan Remaja. Jurnal Psikologi Klinis dan Kesehatan Mental. Vol 1.No 03. 124-132.

Palupi, A. B. (2013). Pengaruh Religiusitas Terhadap Kenakalan Remaja Pada Siswa Kelas VIII SMP Negeri 02 Slawi Kabupaten Tegal.Skripsi. Tidak diterbitkan. Fakultas Ilmu Pendidikan Universitas Negeri Semarang.

Rudati. (2008). Konsep Positve Parenting Menurut Muhammad Fauzil Adhim Dan Implikasinya Terhadap Pendidikan Anak. Skripsi. Tidak diterbitkan. Fakultas Tarbiyah Institut Agama Islam Negeri Walisongo.

Santrock. J. (1995). Life-Span Development. Jakarta: Penerbit Erlangga.

Sari. (2013). Tinjauan Kriminologis Terhadap Kenakalan Remaja (Juvenile Delinquency). Skripsi. Tidakditerbitkan. (Online). Diakses tanggal 12 Agustus 2015,dari (http://repository.unhas.ac.id/)

Sarwono. (2011). Psikologi Remaja. Jakarta: Rajawali Press.

Scohib. (1998). Pola Asuh Orangtua Dalam Membantu Anak Mengembangkan Disiplin Diri. Jakarta. PT. Rineka Cipta.

Spencer. (2013). Familial Religiosity, Family Processes, And Juvinelle Delinquency In A National Sample Of Early Adolescents. Journal of Early Adolescence. Vol 34 (4) 436-462.

Suwaid. (2014). Prophetic Parenting, Cara Mendidik Anak. Yogyakarta: ProMedia.

Upeks Fajar. (2016, Agustus 10). Tim Bhabinkamtibmas jaring 24 siswa bolos.

Diakses tanggal 15 Agustus 2016, dari (http://upeks.fajar.co.id/timbhabinkamtibmas-jaring-24-siswa-bolos/).

Ulwan. (2014). Pendidikan Anak Dalam Islam. Solo: Insan Kamil. 